\title{
Isolation and Characterization of $A$ zospirillum Isolates from Soil and Their Effect on Growth and Yield of Wheat (Triticum aestivum L.) under Different Levels of Nitrogen Fertilizer
}

\section{Mohamed, M.G. ${ }^{1}$; H.M. Mohamed ${ }^{2}$; M. Gameh² ; Hamdia M. El-Rewainy $^{2}$}

${ }^{1}$ Bio-agricultural Center, Aswan.

${ }^{2}$ Department of Soils \& Water, Faculty of Agriculture, Assiut University, Assiut, Egypt. Received on: $12 / 7 / 2018$

Accepted for publication on: 5/8/2018

\section{Abstract}

This study involved isolation of Azospirillum from soils that are different in texture from Aswan governorate. Also, study the response of wheat (Triticum aestivum L.) to inoculation with the isolated Azospirillum strain (M-1, M-2 and M-3) in presence of different levels of nitrogen fertilization (40,60 and $80 \mathrm{~kg}$ $\mathrm{N} / \mathrm{fed}$.) was tested in field experiments in the two seasons 2014/2015 and 2015/2016. Results of the morphological, cultural and physiological characteristics of the three Azospirillum strains (M-1, M-2 and M-3) indicated that they belong to Azospirillum brasilense. Wheat seed inoculation with any of the isolated Azospirillum strains (M-1, M-2 and M-3) induced highly significant increases in all measured growth parameters as well as in total and grain yields and $\% \mathrm{~N}$ in grains. Strains M-1and M-3 were more simulative than M-2 producing the highest total and grain yields. The two interacting factors (inoculation $\mathrm{X} \mathrm{N}$ fertilization level) showed most pronounced mutual effects at the lowest level of $40 \mathrm{~kg} \mathrm{~N} /$ feddan with any of the tested strains compared with the uninoculated treatment. Azospirillum strain M-1was the most reactive at all N-levels. The results also indicate that wheat inoculation with effective Azospirillum strain could save between $20-40 \mathrm{Kg} \mathrm{N}$-fertilizer/feddan.

Keywords: Isolation; Azospirillum; Inoculation; Biofertilizers; Chemical fertilizers.

\section{Introduction}

More recently, a real challenge faces the workers in the agricultural research field to stop using the high rates of agro-chemicals which negatively affect human health and environment. It is well known that wheat crop is considered among the most important cereal crops either in Egypt or all over the world that consumes huge quantities of chemical fertilizers. Many attempts have been tried to replace a part of those harmful chemical fertilizers by biofertilizers to get yield of a good quality without loss in its quantity (El-Kholy et al., 2005). Mishra et al., (1995) have succeeded to reduce the recommended doses of chemical fertilizers needed for corn and millet by $50 \%$ using biofertilizers without loss in the yield.

Azospirillum is one of the plant growth-promoting bacteria that has been found in the rhizosphere and the intercellular of the cereals and other plant roots. Nitrogen fixation, plant growth-promoting hormones production and consequently improving the water and nutrients uptake, increasing the insoluble-phosphates solubility, siderophores and vitamins production, controlling pathogens, synergistic relationship with other useful soil bacteria, nitrite production, bioremediation of the sewage and toxic residues decomposition considered as 
some of the beneficial characteristics of this bacterium that ultimately causes to increase the efficiency and yield of crops (Payne et al., 1981; Brock and Madigan, 1991; Stacey et al., 1992). Produced phytohormones by Azospirillum are effective on respiration rate metabolism, growth and development of root, so they increase water and nutrients uptake in inoculated plants (Holguin et al., 1999). Increasing the efficiency of nutrients uptake through plants was probably due to increase of root surface adsorption as the result of inoculation with growth hormonesproducing bacteria such as Azospirillum (Bashan et al., 2004).

The current investigation was launched to isolate and identify Azospirillum strains from rhizosphere soil and assess the effect of isolated Azospirillum strains on growth and yield of wheat (Triticum aestivum L.) under different levels of nitrogen fertilizer.

\section{Materials and Methods Collection of samples:}

Three Azospirillum strains were isolated from samples of soils that are different in texture collected from Aswan governorate. Strain (M-1) was isolated from the clayey soil and strain (M-2) and (M-3) were isolated from two samples of the sandy soil taken from two separate locations that were cultivated with wheat plants.

\section{Isolation of Azospirillum isolates}

$\mathrm{Nfb}$ (nitrogen free bromothymol) semi-solid medium in screwcapped tubes was inoculated with 0.1 $\mathrm{ml}$ of each sample suspension using a sterile pipette and was incubated at $37^{\circ} \mathrm{C}$ for 72 hours. After incubation Azospirillum appeared in the tubes forming characteristic thin dense, white pellicle few mm below the surface at the medium (Dobereiner, 1980). The pellicles were examined microscopically for the presence of gram negative, vibroid and actively motile cells. According to Krieg (1981), a loopful of the pellicle developed in tubes was transferred to fresh semi-solid $\mathrm{Nfb}$-medium in screw-capped tubes and the tubes were incubated at $37^{\circ} \mathrm{C}$. The white sub-surface pellicle formed after 72 hours in the fresh medium was checked by microscopic examination for the presence of gram negative, curved rmotile cells and transferred into the fresh semi-solid $\mathrm{Nfb}$-medium thrice, each transfer being made at 72 hours intervals. Then a loopful of the pellicle was streaked on the plates of $\mathrm{Nfb}$-medium solidified with $1.5 \%$ agar. The plates were incubated at $37^{\circ} \mathrm{C}$ for one week. Pure colonies (small, dry, slightly convex and rugose) were transferred to the slants of solid $\mathrm{Nfb}$-medium and incubated at $37^{\circ} \mathrm{C}$ for 5 days after then the slant maintained at $4{ }^{\circ} \mathrm{C}$ in a refrigerator.

Morphological and Biochemical study of the Azospirillum isolates:

Microscopic examination of the isolates grown on $\mathrm{Nfb}$ semi-solid and agar media (24 hours and 7-day old cultures) were made for determinations of cell morphology, dimensions, Gram reaction, cell motility and colony characteristics. Besides, the isolates were tested for catalase test, nitrate reduction test, starch hydrolysis test, carbohydrate fermentation test, denitrification test, ammonification test and gelatin-liquification test were made on the physiological activities of the organisms. In each case growth 
of the isolates was recorded by visual observation. All selected isolates were identified according to Bergey's Manual of Determinative Bacteriology (1994).

Efficiency of the isolated strains in fixing of the atmospheric nitrogen:

The nitrogen fixation by each Azospirillum isolates was estimated according to the method described by Humphries (1956). The $\mathrm{N}$ free semi solid malate medium supplied with Lglutamic acid was used in this study. A quantity of $100 \mathrm{ml}$ of the above medium was dispensed to a $250 \mathrm{ml}$ capacity conical flask and autoclaved. The Azospirillum isolates grown for 24 hrs separately in $\mathrm{Nfb}$ broth were used to inoculate $2 \mathrm{ml} / 100 \mathrm{ml}$ of the medium. Duplicate samples were maintained for each isolate. After seven days of incubation at $37^{\circ} \mathrm{C}$ the culture was homogenized. Five $\mathrm{ml}$ of the homogenized culture was collected and digested with $5 \mathrm{ml}$ concentration $\mathrm{H}_{2} \mathrm{SO}_{4}$ and $200 \mathrm{mg}$ catalytic mixture $\left(\mathrm{K}_{2} \mathrm{SO}_{4}: \mathrm{CuSO}_{4}\right.$ : selenium $)$ (100:10:1 ratio) till the contents become clear. After cooling, the volume was made up to $25 \mathrm{ml}$ with distilled water. Then aliquot $5 \mathrm{ml}$ was transferred to microkjeldhal distill unit. An aliquot of $10 \mathrm{ml}$ of 40 percent sodium hydroxide was added and steam distilled. Ammonia evolved was collected over 2 percent boric acid (20 $\mathrm{ml}$ ) containing 2 drops of double indicator $(83.3 \mathrm{mg}$ bromocresol green +
$16.6 \mathrm{mg}$ methyl red indicator dissolved in $10 \mathrm{ml}$ of $95 \%$ ethanol) and back titrated against $0.005 \mathrm{~N} \mathrm{H}_{2} \mathrm{SO} 4$. The nitrogen fixed in vitro was calculated and expressed in $\mathrm{mg} \mathrm{N}$ fixed / $\mathrm{g}$ of malate supplied.

\section{Experiments on wheat:}

Response of wheat (Triticum aestivum L.) to inoculation with the isolated Azospirillum strain (M-1, M2 and $\mathrm{M}-3)$ in presence of different levels of $\mathrm{N}$-fertilization (40, 60 and $80 \mathrm{~kg} \mathrm{~N} /$ fed.) was tested in field experiments at the "Experimental farm of center for Bio-organic Agricultural Researches in Aswan" in the two seasons 2014/2015 and 2015/2016. The local cultivar Seds 1 was used in all experiments. Some physical and chemical properties of soil are presented in Table 1.

The experimental design split plot with 6 replicates was employed in the field experiments. The main plots were devoted to the different levels of N-fertilization 40, 60 and 80 $\mathrm{kg} \mathrm{N} /$ feddan. The subplots were assigned for the treatments of Azospirillum strains. The area of the experimental unit was 1/400 feddan. Grains of each separate plot, uninoculated or inoculated were broadcasted at the rate of $150 \mathrm{~g} /$ plot $(60 \mathrm{~kg} /$ fed. $)$, then slightly covered by surface scratching the seedbed before irrigation. Peat inoculants of the tasted Azospirillum strains were used in these experiments. 
Table 1. Some physical and chemical characteristics of a representative composite soil sample from the experimental site.

\begin{tabular}{|l|c|}
\hline \multicolumn{1}{|c|}{ Property } & Values \\
\hline Clay & 9.3 \\
\hline Silt & 30.5 \\
\hline Sand & 60.2 \\
\hline Texture grade & Sandy loam \\
\hline Total $\mathrm{CaCO}_{3} \%$ & 16.18 \\
\hline $\mathrm{EC} \mathrm{dS} / \mathrm{cm}^{-1}(1: 1)$ & 1.22 \\
\hline $\mathrm{pH}\left(1: 1 \mathrm{suspension}^{\prime}\right)$ & 7.82 \\
\hline Total nitrogen $\%$ & 0.04 \\
\hline Organic matter $\%$ & 0.30 \\
\hline Available $\mathrm{P} \mathrm{mg} \mathrm{g}{ }^{-1}$ soil & 6.67 \\
\hline
\end{tabular}

\section{Inoculant preparation and grains treatment:}

Sterile peat moss was used as a carrier for inoculant preparations. Pulverized dry peat moss, was neutralized to $\mathrm{pH} 7$ with $\mathrm{CaCO}_{3}$ and $\mathrm{Ca}$ $(\mathrm{OH})_{2}$. The treated peat was distributed in batches of $50 \mathrm{~g}$ each in polyethylene bags and autoclaved for 30 minutes at $121^{\circ} \mathrm{C}$ on three successive days. Aliquots of $50 \mathrm{ml}$ of the Azospirillum broth culture (incubated for 6 days at $28-30^{\circ} \mathrm{C}$ ) were added per $50 \mathrm{~g}$ of sterilized carrier material. The grains of each separate plot in polyethylene bag were inoculated by adding $10 \mathrm{ml}$ of $40 \%$ arabic gum solution and $50 \mathrm{~g}$ peat inoculum, then thoroughly mixed until surface coated. Peat inocula contained $10^{8}$ viable cells of Azospirillum/g, determined on plates of $\mathrm{Nfb}$ agar medium. Ammonium nitrate $(33.5 \% \mathrm{~N})$ was used as $\mathrm{N}$-fertilizer and the tested level was add in two doses, the first after 30 days from sowing and the second 30 days later, before spike formation. The plants were irrigated once every 20-30 days until harvest after 5 months from sowing.

\section{Plant sampling:}

Plant samples of 10 plants were taken from each plot, 70 days after sowing. The plants of each sample were taken from different parts of the plot. Immediately after sampling, the plants were transferred to the laboratory, and roots were washed with top water to remove superfluous soil. Plant height was determined, and the sampled plants were separated to shoots and roots for fresh and dry weight determinations. Plant samples were dried at $70^{\circ} \mathrm{C}$ in an air forceddraft oven and their weights were determined. At harvest, total yield was determined for each plot, and plant samples of about $2.3 \mathrm{~kg}$ from each plot were taken for thrashing and grain weight determination, then total grain and straw yields per plot were calculated.

\section{Statistical analysis}

Data obtained in the two seasons were subjected to analysis of variance and the combined analysis of both seasons was used for comparison of means of the different treatments using the least significant difference L.S.D. (Statsoft 1995).

\section{Results and Discussion}

Characteristics of the isolated Azospirillum strains

In this study, 10 different colonies were isolated from rhizosphere soil samples. From these 10 colonies 
of primary selection 3 isolates were selected finally for further study on the basis of their ability to grow better and faster in Nfb semi-solid medium in screw capped test tubes. The selected isolates were $\mathrm{M}-1, \mathrm{M}-2$ and M-3. Results of the morphological, cultural and physiological characteristics of the three Azospirillum strains are presented in Table 2. According to Bergey's Manual of Determinative
Bacteriology (1994), considering all the identifying characteristics selected isolates were identified as Azospirillum brasilense. Variations among the isolates in some characteristics such as colony morphology, starch hydrolysis and fermentation test indicated the different identity of the three isolates, although the observed variations are within the limits of species.

Table 2. Morphological, cultural and physiological characteristics of the isolated Azospirillum strains.

\begin{tabular}{|l|c|c|c|}
\hline \multicolumn{1}{|c|}{ Test } & M-1 & M-2 & M-3 \\
\hline Gram reaction & - & - & - \\
\hline Motility & + & + & + \\
\hline Pellicle formation & + & + & + \\
\hline Colony morphology on Nfb medium & \multicolumn{2}{c|}{} \\
\hline Catalase test & + & + & + \\
\hline Nitrate reduction & + & + & + \\
\hline Starch hydrolysis & - & + & + \\
\hline Gelatin hydrolysis & - & + & + \\
\hline Fermentation test & \multicolumn{2}{|c|}{} \\
\hline Glucose & + & + & + \\
\hline Sucrose & - & - & - \\
\hline Mannitol & + & - & - \\
\hline Lactose & + & - & + \\
\hline Fructose & + & + & - \\
\hline Maltose & + & - & + \\
\hline Ammonification test & - & - & + \\
\hline Denitrification test & + & - & + \\
\hline
\end{tabular}

\section{Efficiency of Azospirillum to fix atmospheric nitrogen}

The amount of nitrogen fixed by Azospirillum strains determined by the microkjeldahl method, were 23.65, 15.32 and $19.75 \mathrm{mg} \mathrm{N}$ per gram of malate utilized, respectively. These results indicate that Azospirillum strain M-1 had higher potential to fix atmospheric nitrogen compared with the other strains (M-2 and M-3). These results are in accordance with the findings of Savalgi et al., (2009) who examined the in vitro $\mathrm{N}$ fixation efficiency of Azospirillum isolates on
$\mathrm{Nfb}$ and reported that nitrogen fixed ranged from 1.4 to $20.96 \mathrm{mg} / \mathrm{g}$ of malate. Purushothaman et al., (1988) reported that the nitrogen fixation potential of Azospirillum sp. varied between 1.6 to $23.96 \mathrm{mg}$ per gram of carbon by Azospirillum strains from cotton genotypes. Azospirillum lipoferum and Azospirillum brasilense showed nitrogen fixation in the range of 7.54 to $24.53 \mathrm{mg}$ of nitrogen per gram of malic acid after seven days at $28^{\circ} \mathrm{C}$. In vitro nitrogen fixation of Azospirillum strains isolated from sorghum under satic conditions. Of 
the 88 Azospirillum isolates, 55 per cent were identified as A. lipoferum and 41.57 per cent as A. brasilense. These represented isolates from the rhizosphere/ endorhizosphere of different ornamental plants. The nitrogen fixing capacity of these isolates ranged from 1.4 to $20.54 \mathrm{mg} \mathrm{N}$ per $\mathrm{g}$ of malic acid in the experiment conducted by Tamilvendan and $\mathrm{Pu}-$ rushothaman (1996).

Response of wheat to Azospirillum inoculation and levels of $\mathrm{N}$ - fertilization:

The combined analysis for the data obtained on wheat growth and yield in two successive seasons is presented in Table (3) showing the main effects of $\mathrm{N}$-fertilization levels and inoculation with the isolated Azospirillum strains. The results showing that wheat seed inoculation with any of the isolated Azospirillum strains (M-1, M-2 and M-3) induced highly significant increases in all measured growth parameters as well as in total and grain yields and $\% \mathrm{~N}$ in grains. Strains M-1and M-3 were more simulative than M-2 producing the highest total and grain yields (Table 3 ).

Under field conditions the rate of $\mathrm{N}$-fertilization had significant influence on plant growth and yield, showing significant additive increases with the increase in N-level from 40 up to $80 \mathrm{~kg} \mathrm{~N} /$ feddan. The maximum values recorded at the $80 \mathrm{~kg}$-level were significantly higher than those recorded at the $60 \mathrm{~kg}$-level for fresh weight of shoots and roots, total and grain yields and total $\mathrm{N}$ in grains.

Table (4) show the interaction effects of $\mathrm{N}$-fertilization levels and Inoculated Azospirillum strains on plant growth and yield of wheat. The two interacting factors (inoculation $\mathrm{X}$ $\mathrm{N}$-fertilization level) showed most pronounced mutual effects at the lowest level of $40 \mathrm{~kg} \mathrm{~N} / \mathrm{fed}$. with any of the tested strains compared with the uninoculated treatment. At the higher $\mathrm{N}$-fertilization levels (60 and $80 \mathrm{~kg} \mathrm{~N} / \mathrm{Fed}$.) the increases in plant growth and yield induced by the tested strains tended to decrease, yet the differences were still significant compared with the uninoculated treatment.

Azospirillum strain M-1was the most reactive at all N-levels. At the $40 \mathrm{Kg} \mathrm{N}-\mathrm{level}$, this strain scored the highest grain yields of $8.35 \mathrm{Kg} /$ plot compared with $4.94 \mathrm{Kg}, 7.69 \mathrm{Kg}$ and $9.22 \mathrm{Kg}$ grain yield/plot produced in the uninoculated treatments with, 40 , 60 and $80 \mathrm{Kg} \mathrm{N} /$ fed., respectively. (Table 4). This confirms the superiority of the isolated Azospirillum strain M-1in comparison with M-2 and M3. The results also indicate that wheat inoculation with effective Azospirillum strain could save between 20-40 $\mathrm{Kg} \mathrm{N}$-fertilizer/feddan. The significant increase in total and grain yields recorded in the inoculated treatments are probably due to N2-fixation and the hormonal effects by the inoculated Azospirillum strains. Positive impacts on plant growth by Azospirillum through several mechanisms include enhancement of root development, production of growth regulators and nitrogen fixation (Okon et al., 1994; Garci'a de Salamone et al., 1996). The content of nitrogen, phosphorus, potassium and various micronutrients is higher in plants inoculated with Azospirillum (CaballeroMellado et al., 1992). 
Table 3. The main effects of $\mathrm{N}$ - fertilization levels and inoculation with Azospirillum strains on wheat, cv.Seds1. grown on a sandy loam soil Combined analysis of the two seasons of 2013/2014 and 2014 / 2015

\begin{tabular}{|c|c|c|c|c|c|c|c|c|c|}
\hline \multirow[t]{2}{*}{ Treatments } & \multirow{2}{*}{$\begin{array}{c}\text { Average } \\
\text { plant } \\
\text { height } \mathrm{cm}\end{array}$} & \multicolumn{2}{|c|}{$\begin{array}{l}\text { Shoot wt. } \\
\text { g/plant }\end{array}$} & \multicolumn{2}{|c|}{$\begin{array}{l}\text { Root wt. } \\
\text { g/plant }\end{array}$} & \multicolumn{3}{|c|}{ Yield kg/plot* } & \multirow{2}{*}{$\begin{array}{c}\text { N-in } \\
\text { Grains } \\
\%\end{array}$} \\
\hline & & Fresh & Dry & Fresh & Dry & Straw & Grains & Total & \\
\hline \multicolumn{10}{|l|}{$\begin{array}{l}\text { N-fertilization } \\
\text { (kg N/feddan) }\end{array}$} \\
\hline 40 & 101.35 & 44.80 & 7.50 & 2.73 & 1.11 & 13.87 & 5.93 & 23.80 & 2.33 \\
\hline 60 & 104.72 & 45.39 & 10.36 & 3.26 & 1.45 & 17.24 & 9.02 & 29.95 & 2.43 \\
\hline 80 & 106.53 & 52.64 & 10.78 & 3.36 & 1.78 & 18.73 & $9 . .86$ & 32.53 & 2.22 \\
\hline L.S.D $\quad 0.05$ & 1.43 & 3.32 & 0.63 & 0.26 & 0.14 & 0.90 & 0.53 & 1.01 & 0.06 \\
\hline \multicolumn{10}{|l|}{ Inoculated strains } \\
\hline \multirow{4}{*}{$\begin{array}{c}\text { Uninoc. } \\
\text { strain M-1 } \\
\text { strain M-2 } \\
\text { strain M-3 }\end{array}$} & 101.67 & 45.28 & 6.89 & 2.56 & 1.12 & 14.55 & 6.13 & 24.55 & 2.32 \\
\hline & 104.49 & 52.11 & 9.7 & 3.67 & 1.56 & 17.39 & 9.15 & 30.46 & 2.41 \\
\hline & 103.23 & 46.56 & 9.90 & 3.45 & 1.53 & 18.11 & 8.65 & 29.43 & 2.44 \\
\hline & 107.32 & 47.13 & 11.05 & 3.78 & 1.45 & 16.65 & 9.11 & 30.70 & 2.42 \\
\hline L.S.D $\quad 0.05$ & 1.64 & 4.72 & 0.83 & 0.40 & 0.28 & 0.93 & 0.52 & 1.14 & 0.07 \\
\hline Season: & & & & & & & & & \\
\hline 1 & 102.19 & 45.71 & 8.35 & 2.87 & 1.25 & 15.53 & 7.63 & 27.26 & 2.42 \\
\hline 2 & 106.32 & 49.50 & 10.30 & 3.57 & 2.03 & 16.61 & 8.89 & 29.35 & 2.45 \\
\hline L.S.D & 1.15 & 3.35 & 0.62 & 0.31 & 0.20 & 0.65 & 0.36 & 0.80 & 0.05 \\
\hline
\end{tabular}

*The area of each plot $=1 / 400$ feddan

Table 4. The interaction effects of $\mathrm{N}$-fertilization levels and inoculation with Azospirillum strains on wheat, cv. Seds 1. grown on a sandy loam soil Combined analysis of the two seasons of $2013 / 2014$ and $2014 / 2015 * *$.

\begin{tabular}{|c|c|c|c|c|c|c|c|c|c|c|}
\hline \multirow{2}{*}{\multicolumn{2}{|c|}{$\begin{array}{c}\text { Treatments } \\
\text { N-fert. } x \text { inocu- } \\
\text { lated } \\
\text { (kg N/fed.) } \\
\text { strain }\end{array}$}} & \multirow{2}{*}{$\begin{array}{c}\text { Average } \\
\text { plant } \\
\text { height } \\
\text { cm }\end{array}$} & \multicolumn{2}{|c|}{$\begin{array}{l}\text { Shoot wt. } \\
\text { g/plant }\end{array}$} & \multicolumn{2}{|c|}{$\begin{array}{l}\text { Root wt. } \\
\text { g/plant }\end{array}$} & \multicolumn{3}{|c|}{$\begin{array}{c}\text { Yield } \\
\mathrm{kg} / \text { plot*}^{*}\end{array}$} & \multirow{2}{*}{$\begin{array}{c}\mathrm{N} \text {-in } \\
\text { grains } \%\end{array}$} \\
\hline & & & Fresh & Dry & Fresh & Dry & Straw & Grains & Total & \\
\hline \multirow{4}{*}{40} & Uninoc. & 99.76 & 38.30 & 5.14 & 2.11 & 0.59 & 10.10 & 4.94 & 14.45 & 2.23 \\
\hline & strain M-1 & 103.10 & 61.26 & 8.65 & 2.76 & 1.10 & 16.23 & 8.35 & 24.58 & 2.32 \\
\hline & strain M-2 & 101.45 & 44.82 & 8.12 & 2.64 & 1.07 & 18.29 & 7.27 & 25.53 & 2.24 \\
\hline & strain M-3 & 102.93 & 44.91 & 8.36 & 2.29 & 1.33 & 15.13 & 7.57 & 22.70 & 2.36 \\
\hline \multirow{4}{*}{60} & Uninoc. & 101.76 & 43.11 & 9.22 & 2.55 & 0.95 & 17.18 & 7.69 & 24.88 & 2.38 \\
\hline & strain M-1 & 103.80 & 50.80 & 11.27 & 4.39 & 1.25 & 18.55 & 10.92 & 29.50 & 2.46 \\
\hline & strain M-2 & 104.33 & 43.54 & 10.12 & 3.44 & 1.45 & 18.53 & 10.63 & 29.23 & 2.46 \\
\hline & strain M-3 & 111.91 & 53.17 & 12.66 & 3.28 & 1.96 & 18.57 & 10.77 & 28.36 & $2 . .50$ \\
\hline \multirow{4}{*}{80} & Uninoc. & 103.33 & 55.46 & 8.49 & 2.61 & 1.00 & 19.12 & 9.22 & 28.26 & 2.38 \\
\hline & strain M-1 & 106.71 & 55.90 & 8.36 & 4.11 & 1.81 & 20.05 & 11.22 & 31.28 & 2.42 \\
\hline & strain M-2 & 106.00 & 56.09 & 11.53 & 4.07 & 1.540 & 20.18 & 11.26 & 31.51 & $2 . .46$ \\
\hline & strain M-3 & 110.10 & 54.95 & 12.16 & 3.90 & 1.60 & 19.27 & 11.18 & 31.28 & 2.45 \\
\hline L.S. & $\begin{array}{ll}D & 0.05\end{array}$ & 3.81 & 8.80 & 1.73 & 0.75 & 0.40 & 2.43 & 1.50 & 2.65 & 0.16 \\
\hline
\end{tabular}


Most of the studies of the Azospirillum plant association have been conducted on cereals and grasses (Tyler et al., 1979) and only a few other plant families have been investigated (Bashan et al., 1989). Plant response to inoculation with Azospirillum in cereals and non cereals are often reported in terms of increased grain yield, plant biomass, nutrient uptake, grain and tissue $\mathrm{N}$ contents, nitrogenase activity, early flowering, tiller numbers, greater plant height and leaf size, increased number of spikes, grains per spike, test weight, increased root length and volume. The responses varied with crops, cultivators, locations, seasons, agronomic practices, bacterial strains, soil fertility and interaction with native soil microflora (Wani, 1990). The increase in the stem diameter of maize and increase in the number of ear and tillers in wheat was attributed to the production of plant growth promoting substances by Azospirillum (Kapulnik et al., 1981). Among the three plant growth promoting substances produced by the Azospirillum, auxins were quantitatively more. The bacterial IAA biosynthesis has been thoroughly studied in A. brasilense. Azospirillum possess at least 3 IAA biosynthesis pathways of which, two are tryptophan dependent and the other is tryptophan independent. Piccinin et al. (2011) evaluated the agronomic efficiency of Azospirillum brasilense in physiological parameters and yield components of wheat under reduced $\mathrm{N}_{2}$ fertilization. Their work showed that the use of half level of $\mathrm{N}_{2}$ associated with the inoculation of seeds with $A$. brasilense promoted results on the agronomic performance and productivity of wheat.

\section{References}

Bashan, Y., Holguin, G. and de-Bashan, L. E. (2004). Azospirillum-plant relationships: physiological, molecular, agricultural, and environmental advances (1997-2003). Can. J. Microbiol., 50(8), 521-577.

Bashan., Ream, Y., Levanony, H. and Sade, A. (1989). Non specific responses in plant growth, Yield and root colonization of non- cereal; crop plants to inoculation with Azospirillum brasilense d. can,. J. Bot., 67: 1317.

Brock, F. D. and Madigan, M. T. (1991). Biology of Microorganism, $6^{\text {th }}$ edi., Prentice Hall, USA.

Caballero-Mellado, J., Carcan oMontiel, M. and Mascaru'aEsparza, M.A. (1992). Field inoculation of wheat (Triticum aestivum) with Azospirillum brasilenseunder temperate climate, Symbiosis 13: 243-253.

Daltimor, M.D. (1994). Bergey's Manual of Determinative Bacteriology, $9^{\text {th }}$ ed, Williams and wilkins company.

Dobereiner J. (1980). Forage Grasses and grain crops, In: methods of evaluating biological nitrogenfixation, Bergersen, f. J. (ed)., John Wiley and Sons, New York, 541555.

El-Kholy, M.A., El-Ashry, S. and Gomaa, A.M. (2005). Biofertilization of Maize Crop and its Impact on Yield and Grains Nutrient Content under Low Rates of Mineral Fertilizers. Journal of Applied Sciences Research 1(2): 117-121.

Garci'a de Salamone, I.E., Do "bereiner, J., Urquiaga, S. and Boddey, R.M. (1996). Biological Nitrogen Fixation in Azospirillumstrain-maize genotype associations as evaluated by $15 \mathrm{~N}$ isotope dilution technique, Biol. Fertil. Soil. 23: 249-256. 
Holguin, G., Patten, C.L., Glick, B.R. (1999). Genetics and molecular biology of Azospirillum. Biol. Fertil. Soils, 29, 10-23.

Humphries E.C., (1956). Mineral components and ash analysis, In: modern methods of plant analysis, Ed. Peach, K. and Tracey, M. V., Springer, Verlag Berlin, pp. 446502.

Kaplunik, Y., Kiget, J., Okon, Y; Nur, I. and henis, Y. (1981). Effect of Azospirillum inoculation on some growth parameters and $\mathrm{N}$-content of wheat, sorghum and panicnm plant and soil, 61: 65-70.

Krieg N.R. (1981). Enrichment and isolation, In: Manual of Methods for general bacteriology, Gerhardt P, (ed), American soc. Microbiol. Washington, 112- 142.

Mishra, O.R., Tomar, V.S., Sharma, R.A. and Rajput, A.M. (1995). Response of maize to chemical and biofertilizers. Crop Res. (Hisar). 9 (2): $233-237$.

Okon, Y. (1994). In: Y. Okon (Ed.), Azospirillum/Plant Association, CRC Press, Boca Raton, Florida, USA.

Payne, W.J., Sherr, B.F. and Chalmers, A. (1981). Nitrificationdenitrification associated with plant roots. In: Vose, P. B., and Ruschel, A. P. (eds.). Associative N2-Fixation. Florida: CRC Press. pp. 37-48.

Piccinin, GG., Dan, G., L.M., Braccini, A.L.E., Mariano, D.C., Okumura, RS. and Gabriel, L. B. and Ricci, T.T. (2011). Agronomic effen- ciency of Azospirillum brasilense in physiological param eters $\mathrm{J}$. Agron., 10 (4): 132- 135.

Purushothaman, D., Jayanath, M., K. and Giunashekaran, S. (1988). Association of Azospirillum with the Roots of upland Rice, P. nayaprakash, Calcutta, pp.120125.

Savalgi, V. P., On Karappa, R., Veena, S. and Gurumurthy, S. B. (2009). Screening of plant grown promotional actirites and diazotrophic activites of Azospirillum Strains from vertisols of northern Karnataka. Rarnataka J. Agric. Sci., 22(5): 1126-1129.

Stat Soft, (1995). Statistica for Windows (Computer Program manual). StatSoft, Inc., Tulsa, OK.

Stacey, G., Burris, R. H. and Evans, H. J. (1992). Biological Nitrogen Fixation. Chapman and Hall, New York.

Tamilvendan, K., and purushothaman, D., (1996). Dereloping phosphorus solubilizing strains in Azospirillum Proceedings of the national seminar on Microorganisms in sustainable Agriculture, madural pp. 7989.

Tyler, M. E., Milam, J. R., Smith, R. L., Schank, S. C. and Suberer, D. A. (1979). Isolation of Azospirillum from diverse geographic regions. Can. J. Microbiol., 25: 693-697.

Wani, S. P. (1990). Inoculation with associative nitrogen fixing bacteria: role in cereal grain production improvement. Indian J. Microbiol., 30:363-393. 
عزل وتوصيف الأزوسبيريلا المعزولة من التربة وتأثيرها على نمو ومحصول القمح تحت مستويات مختلفة من التسميل النيتروجيني

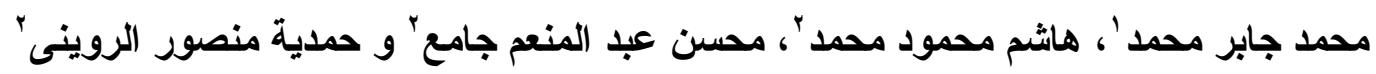

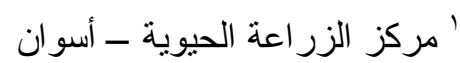

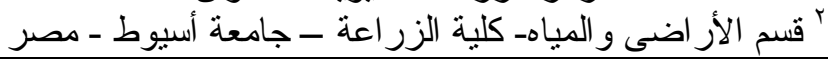

تم في هذا البحث عزل ثلاث سـلالات من بكتريـا الأزوسبيريلا من أر اضي مختلفة القو ام بمحافظة أسو ان.

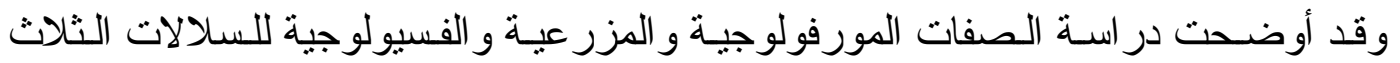

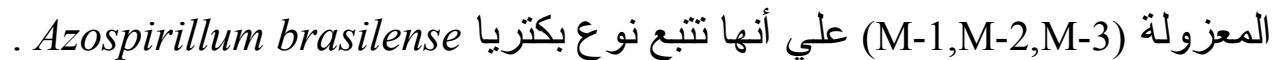

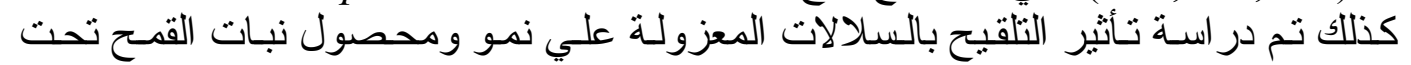

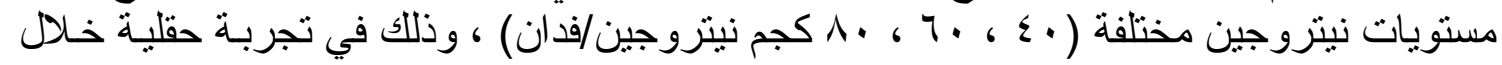

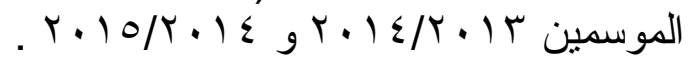

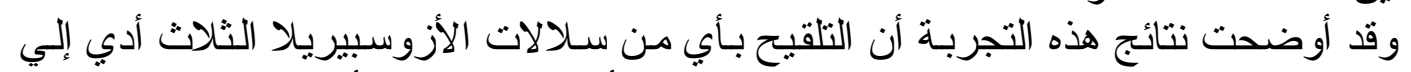

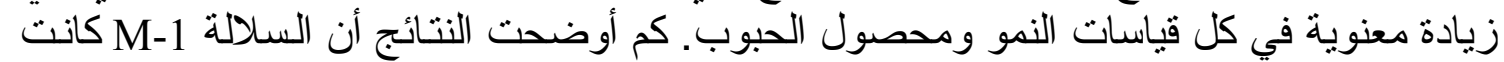

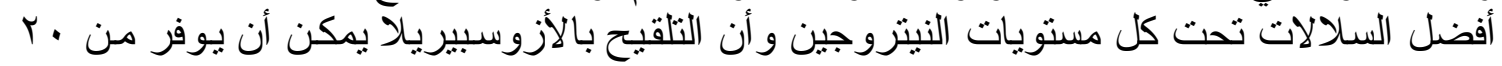

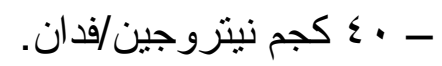

